\title{
Technique
}

\section{A single intestinal intubation technique for multiple function studies}

\section{A. E. COWEN AND C. B. CAMPBELL From the Depart- ment of Gastroenterology, Royal Brisbane Hospital, Queensland, Australia}

Intestinal intubation is required for accurate diagnosis in a variety of gastrointestinal diseases. Repeated intubations are often performed when intestinal biopsy, pancreatic function tests, and even bacteriological studies are consecutively found to be necessary. Intubation is considered unpleasant by the majority of patients and some find repeated studies frankly distressing. This paper describes a technique allowing a wide variety of intestinal function studies to be undertaken with a single intubation as an outpatient procedure.

\section{Materials}

Materials used include $120 \mathrm{~cm}$ of double-lumen PVC tubing $6 \mathrm{~mm}$ in external diameter ${ }^{1}$, polythene tubing $150 \mathrm{~cm}$ long and $1.57 \mathrm{~mm}$ external diameter ${ }^{2}$, a standard Watson capsule ${ }^{3}$, and small aspirating motor $^{4}$ with collecting bottles.

\section{Design}

Aspiration holes are cut in the distal $15 \mathrm{~cm}$ of one side of the double-lumen tube and the fine polythene tubing is passed through this lumen and attached to the Watson capsule. The other side of the doublelumen tube is sealed with a radiopaque marker, 25 $\mathrm{cm}$ from the distal end, and aspiration holes are cut in the $15 \mathrm{~cm}$ above this (Fig. 1).

\section{Procedure}

The patient is starved overnight and intubated after

${ }^{1}$ PVC multibore tubing, MLT/C; Portex Ltd, Hythe, Kent, England.

'Polythene tubing pp. 160 Portex Ltd, Hythe, Kent, England.

'Watson capsule, Down Bros. and Mayer \& Phelps Ltd, Church Path, Mitcham, Surrey, England.

'Dymax MK 1 Charles Austen Pumps, 100 Royston Road, Byfleet, Surrey, England.

Received for publication 26 July 1971.

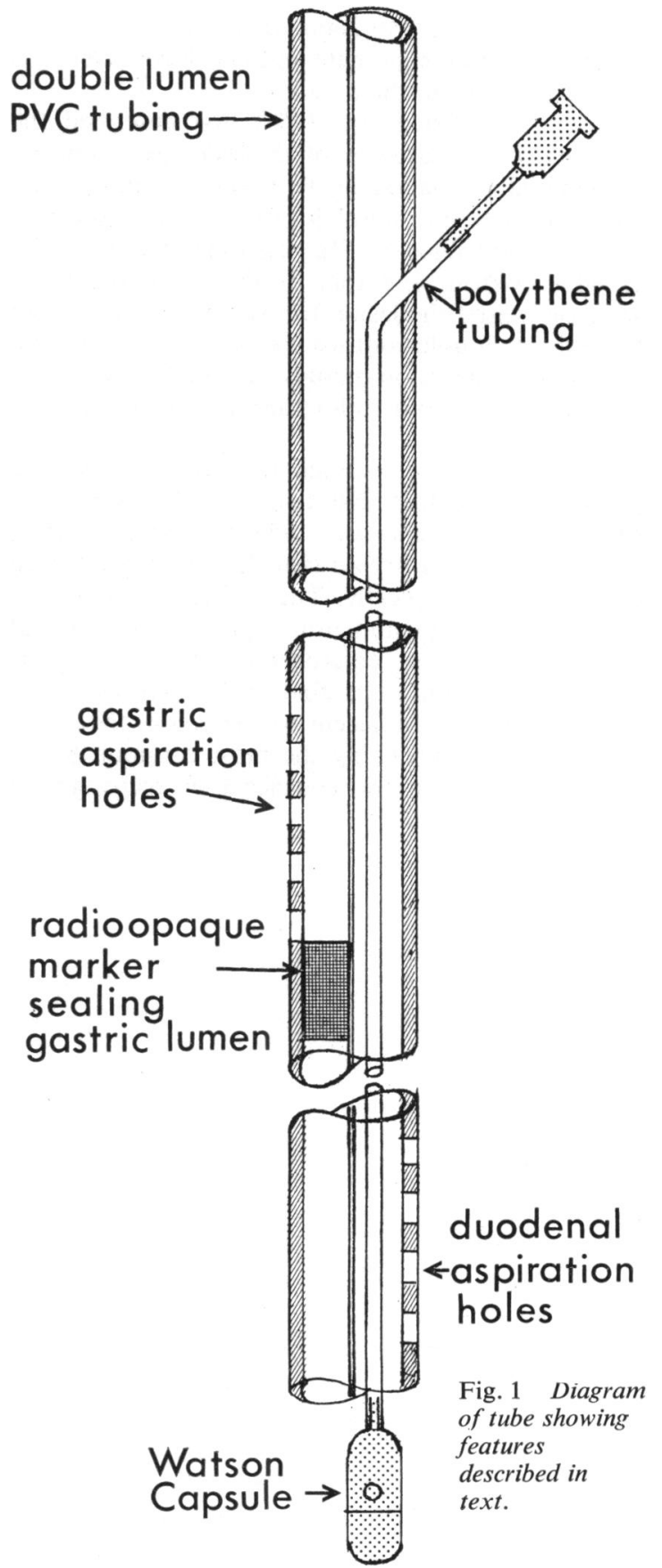




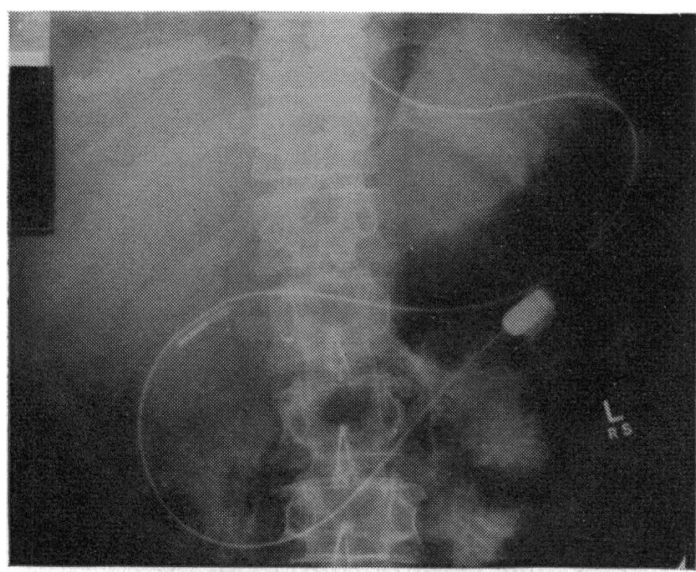

Fig. 2 Radiograph showing tube in place. The inner polythene tube has been opacified using Gastrografin which has entered the upper jejunum.

anaesthetizing the pharynx with local anaesthetic. The radiopaque marker is positioned at the pylorus under $x$-ray control with image intensification. The length of the tube is such that, when the radiopaque marker lies at the pylorus, the Watson capsule will lie in the vicinity of the ligament of Trietz (Fig. 2). With the use of intravenous metochlopramide and posture the tube can usually be positioned in under 30 minutes. Gastrografin may be used to assist in positioning the tube if difficulty is encountered. However, if pancreatic function studies are to be performed it should be noted that Gastrografin may interfere with certain methods of trypsin assay (Cowen, McGeary, and Campbell, 1971).

Some gastric function studies, including measurement of fasting $p \mathrm{H}$ and gastric antibodies, may be performed on secretions aspirated via the gastric lumen. However, the tube is not suitable for basal and stimulated acid secretion studies because of pyloric reflux with the tube in position. The duodenal lumen allows examination of upper small intestinal aspirates for bacteriological studies including culture, colony counts, presence of deconjugated bile salts, and examination for parasites. Pancreatic function may be assessed according to the method of Burton, Evans, Howat, Oleesky, Scott, and Varley (1960) or by the technique described by Lundh (1962). Further bile salt studies may be carried out on post-pancreozymin specimens or after indirect stimulation by the Lundh meal. At the conclusion of studies the position of the Watson capsule is checked radiologically and the capsule fired. The tube is removed and the mucosal specimen may be divided into several pieces for histological examination, estimation of disaccharidase activity, and immunofluorescent staining.

The advantages of this technique are that the procedure can be performed on an outpatient basis, only a single intubation is required, and the whole study is performed in three to four hours.

We are grateful to Mr Brian Stewart for the photographs and to Mrs Joan Phillips, research secretary supported by G. D. Searle (Australia) Pty. Ltd. One of us (C.B.C.) is in receipt of an Abbott fellowship from the Royal Australasian College of Physicians.

\section{References}

Burton, P., Evans, D. G., Harper, A. A., Howat, H. T., Oleesky, S., Scott, J. E., and Varley, H. (1960). A test of pancreatic function in man based on the analysis of duodenal contents after administration of secretin and pancreozymin. Gut, 1, 111-123.

Cowen, A. E., Campbell, C. B., and McGeary, H. (1971). Interference with colorimetric method of trypsin assay by gastrografin. (In preparation.)

Lundh, G. (1962). Pancreatic exocrine function in neoplastic and inflammatory disease; a simple and reliable new test. Gastroenterology, 42, 275-280. 